\title{
A Model of Reliability Optimization \\ of a Stand-Alone Electric Power System \\ with Constraints on Dynamic Stability \\ of the Wind Turbine
}

\author{
Sergej M. Perzhabinsky*a, \\ Dmitriy N. Karamov and Andrei A. Achitaev ${ }^{\mathrm{b} *}$ \\ ${ }^{a}$ Melentiev Energy Systems Institute of the SB RAS \\ Irkutsk, Russian Federation \\ ${ }^{b}$ Siberian Federal University \\ Sayanogorsk, Russian Federation
}

Received 20.01.2020, received in revised form 09.02.2021, accepted 21.02.2021

\begin{abstract}
The relevance of the study is due to the development herein of a model for reliability optimization of stand-alone power systems with wind turbines and electrochemical power storage devices, with special emphasis within this model put on the specifics of power equipment operation. The key feature of the model developed is that it enables us to factor in the requirements to be met by the equipment as arising from the considerations of dynamic stability of the stand-alone system. When simulating battery storage operating modes, the charge-discharge limits as well as the remaining charge in the storage are taken into account. Thus, the reduction of the total number of considered mixes of the equipment being commissioned is achieved, the computational efficiency of the reliability optimization method is increased, while the validity of modeling results is improved. Development of methods for optimization of reliability of stand-alone electric power systems with wind turbine installations and electrochemical power storage devices while meeting requirements for electrodynamic stability. A stand-alone power system that is assumed to be located in the coastal area of Lake Baikal in the Kabansky State Nature Reserve, Republic of Buryatia, Russia, serves as the object of the study. Calculations are based on multiple simulation of modes of operation of the electric power system by means of the Monte Carlo method. The values of random variables are modeled as per specified laws of distribution and fault rate indicators of power equipment. Modeling of power generation at wind turbines is based on a detailed analysis of real-life weather data (average hourly wind speed, air density and humidity). The method of reliability optimization of stand-alone power systems with wind turbines and electrochemical energy storage devices was developed so as to take into account the requirements to be met by electric power equipment in terms of dynamic stability. The optimization criterion is the minimum expected value of the cost of produced electricity. Power redundanct and energy storage devices are used as means of reliability assurance. The results of calculations attest to
\end{abstract}

(C) Siberian Federal University. All rights reserved

This work is licensed under a Creative Commons Attribution-Non Commercial 4.0 International License (CC BY-NC 4.0).

* Corresponding author E-mail address: sergperj@gmail.com

ORCID: 0000-0002-3225-2558 (A. Achitae) 
the fact that for the natural and climatic zone under consideration, the use of vertical axis wind turbines in a stand-alone power system proves more efficient than the use of horizontal axis wind turbines.

Keywords: stand-alone power system, resource adequacy, reliability optimization, dynamic stability, Monte Carlo method, wind turbines, storage battery.

Citation: Perzhabinsky S.M., Karamov D.N., Achitaev A.A. A Model of reliability optimization of a stand-alone electric power system with constraints on dynamic stability of the wind turbine, J. Sib. Fed. Univ. Eng. \& Technol., 2021, 14(1), 55-71. DOI: $10.17516 / 1999-494 X-0288$

\title{
Модель оптимизации надежности
}

\section{автономной электроэнергетической системы \\ с ограничениями}

\section{на динамическую устойчивость ветрогенератора}

\author{
С.М. Пержабинский \\ ${ }^{a}$ Институт систем энергетики им. Мелентьева \\ Российская Федерачия, Иркутск \\ ${ }^{6}$ Сибирский федеральный университет \\ Российская Федерация, Саяногорск
}

\begin{abstract}
Аннотация. Актуальность исследования обусловлена разработкой в данной работе модели оптимизации надежности автономных энергосистем с ветрогенераторами и электрохимическими накопителями энергии, при этом особое внимание в рамках данной модели уделяется специфике эксплуатации энергетического оборудования. Ключевая особенность разработанной модели заключается в том, что она позволяет учитывать требования, предъявляемые к оборудованию, как вытекающие из соображений динамической устойчивости автономной системы. При моделировании режимов работы аккумуляторных батарей учитываются пределы зарядаразряда, а также оставшийся заряд в накопителе. Таким образом, достигается сокращение общего числа рассматриваемых вариантов вводимого в эксплуатацию оборудования, повышается вычислительная эффективность метода оптимизации надежности и повышается достоверность результатов моделирования. Цель: разработка методов оптимизации надежности автономных электроэнергетических систем ветроэнергетическими установками и электрохимическими накопителями энергии при соблюдении требований к электродинамической устойчивости. Объектом исследования является автономная энергосистема, предположительно расположенная в прибрежной зоне озера Байкал в Кабанском государственном природном заповеднике Республики Бурятия. Расчеты основаны на многократном моделировании режимов работы электроэнергетической системы методом Монте-Карло. Значения случайных величин моделируются в соответствии с заданными законами распределения и показателями аварийности энергетического оборудования. Моделирование выработки электроэнергии на ветрогенераторах основано на детальном анализе реальных погодных данных (среднечасовая скорость ветра, плотность и влажность воздуха). Разработана методика оптимизации надежности автономных энергосистем с ветрогенераторами и электрохимическими накопителями энергии с учетом требований, предъявляемых к электроэнергетическому оборудованию с точки зрения динамической устойчивости. Критерием оптимизации является минимальное ожидаемое значение себестоимости произведенной электроэнергии. В качестве средств обеспечения надежности используются устройства резервирования мощности и накопления
\end{abstract}

$$
-56-
$$


энергии. Результаты расчетов свидетельствуют о том, что для рассматриваемой природноклиматической зоны использование ветрогенераторов с вертикальной осью в автономной энергосистеме оказывается более эффективным, чем использование ветрогенераторов с горизонтальной осью.

Ключевые слова: автономная энергосистема, ресурсная адекватность, оптимизация надежности, динамическая устойчивость, метод Монте-Карло, ветрогенераторы, аккумуляторная батарея.

Цитирование: Пержабинский, С.М. Модель оптимизации надежности автономной электроэнергетической системы с ограничениями на динамическую устойчивость ветрогенератора / С.М. Пержабинский, Д.Н. Карамов, А.А. Ачитаев // Журн. Сиб. федер. ун-та. Техника и технологии, 2021, 14(1). С. 55-71. DOI: 10.17516/1999-494X-0288

\section{Introduction}

Integration of renewable energy sources into centralized and autonomous power systems requires a number of theoretical and applied problems to be solved. Such problems include the following: mathematical modeling of power system elements, making up of initial arrays of natural and climatic data, analysis of power supply reliability in these power systems, solving problems of equipment mix optimization. The following can serve as optimization criteria: the minimum of levelized cost of electricity, the maximum saving of fossil fuel, the minimum undersupply of electricity to the consumer, etc. [1].

Our analysis of the published research that deals with issues of the reliability of electric power systems with renewable energy sources backs up our conclusion that recently the academics have been seeking to detail their studies and to take into account various aspects of the operation of these power systems, which certainly increases the efficiency and importance of the research findings thus obtained. To illustrate, the study [2] provides a detailed review and classification of reliability indicators for power systems with a high share of renewable energy sources. Combinations of reliability indicators are offered, as constructed from the point of view of technical and economic performance efficiency, the flexibility of the power system operation, and availability of initial statistical data. The article [3] investigates a stand-alone hybrid power system with photovoltaic converters, fuel cells, solar panels, and a heat recovery system. In this study, the issues of power supply and heat supply are treated in an integrated fashion, an overall indicator of system reliability with the calculation of the probability of fault-free operation is introduced. To this end, the problem of optimization of the mix of equipment with determining the most suitable engineering solution that meets the criteria of the minimum levelized cost of energy and the maximum value of the general indicator of reliability of the system is discussed. Thus, the range of Pareto optimal solutions is determined. The study [4] addresses the issues of ensuring sustainability and reliability of the power system that has generators run by renewables. This paper uses real-life data from the state of Texas (USA), presents the existing structure of generation, energy transportation, and various scenarios of energy system development to 2030. Data are given on current operation of the energy system, load factors of energy facilities, and their stable operation in case of instability of wind turbine generation. The article [5] discusses the failures of elements of wind turbines that are part of offshore wind farms. This contribution describes the method and software that implements it. The algorithm behind reliability analysis of wind turbines operation is made up of 7 modules with the following being factored in: technical features of employed wind turbines; long-term average monthly values of climatic indicators; a climatic model forming an 
array with the discrete step of 6 hours; detailed mathematical models of wind turbine components with the simulation of their failures; a model of power generation by the wind turbine. The reliability analysis model makes an allowance for the estimated time required to eliminate the failure of each element of an offshore generating set. The study [6] analyzes the reliability indicators of the standalone wind-diesel hybrid system. The article proposes an approach to the development of a faulttree based probabilistic logic method. Calculation of reliability indicators is based on the intensity of failures of system elements and relative duration of failures. The presented overview is conclusive of the need for detailed consideration of specifics of power equipment operation when studying the reliability of power supply in power systems with generation fired by renewables. An overview of reliability optimization methods and reliability analysis models can be found, for example, in $[1,7]$.

When integrating wind power plants into the electric power system there is a problem of ensuring dynamic stability of the power supply system [8-10]. The above problem is manifested in the fact that given a sudden reduction of electrical load, an excess of active power leads to frequency growth in the power system and, as a consequence, to the potential asynchronous run. Therefore, some countries have developed and approved requirements for connecting wind farms to the power system. In particular, there are constraints on the value of installed capacity of the wind farm generating power for shared buses of the electric power system [11]. Additionally, as a countermeasure to the asynchronous run in stand-alone electric power systems, DC inserts [12], energy storage devices [11, 13], magnetic gearboxes and variators in wind turbines [14], elements of emergency control automatics [15] are used.

The use of power storage devices in stand-alone power systems allows smoothing out the imbalance of generated and consumed power, thus ensuring the stability of the system operation. In stand-alone electric power systems it is expedient to use electrochemical energy storage devices, which compare favorably to other types of energy storage facilities having the advantage of good performance characteristics and relatively low cost. The options for the storage link layout in the stand-alone power system are formed depending on the mix of generating equipment and modes of its operation. For example, in photovoltaic systems with strongly pronounced cyclic charge/discharge modes it is necessary to use OPzS type storage batteries (shell-type flooded lead-acid storage batteries), FLA (long service life flooded lead-acid storage batteries), LCB (lead-carbon batteries), LIB (lithium-ion batteries), and, in some cases, $\mathrm{OPzV}$ (lead-acid batteries with shell-type gel electrolyte). In electric power systems with wind turbines it is recommended to use OPzS-type storage batteries characterized by high values of rated charge-discharge currents, a large number of charge-discharge cycles, and an affordable price

The purpose of this article is to develop and demonstrate a method for optimizing the reliability of a stand-alone power system taking into account the requirements to be met by power equipment in terms of electrodynamic stability. The stand-alone power system consists of wind turbines operating in parallel with a diesel generator and storage batteries. The criterion of reliability optimization is the minimum expected value of the cost of produced electricity. The experimental studies considered a stand-alone consumer with typical load profiles for four seasons of the year within the Baikal climatic zone of Kabansky District, Republic of Buryatia, Russia. Weather data (average hourly wind speed, air density) were broken down into four seasons of the year and processed for a ten-year period.

The paper is made up of five sections, an introduction, a conclusion, and a reference list. The first section discusses the issues of electrodynamic stability and substantiates constraints on the choice of power equipment. The second section presents the description of reliability optimization methodology, 
a simulation model of power supply system operation, a reliability analysis model, and a reliability optimization model. The third section is devoted to the peculiarities of modeling of different types of wind generators, electricity storage devices, as well as technical and cost characteristics of power equipment. The fourth section presents the following: a description of the object of the study, that is a stand-alone hybrid power system located in the natural and climatic zone of Lake Baikal, Republic of Buryatia, Russia; an analysis of weather data in this region. The fifth section contains the results of optimization of equipment mix of the investigated stand-alone power system.

\section{Stability of operation of a stand-alone electric power system}

Operation of wind turbines as part of stand-alone power systems with diesel generators has a number of special aspects to it. In particular, when there are abrupt changes in the mode of electric load or wind speed, there is a short-term excess of active power, which leads to acceleration of generators. Therefore, within a stand-alone hybrid power system, one can observe an asynchronous run with respect to the generators that keep operating [14]. The low moment of inertia of the synchronous generator rotors and virtually zero moment for the frequency converter lead to the asynchronous run. Therefore, the modern development of the distributed sources of electric power is impossible without perfecting the means that would allow to improve the controlling capability of the generating equipment, and, as a consequence, to ensure the redundancy of the dynamic stability of the stand-alone electric power system in case of abrupt changes in its mode of operation. It is important to highlight the influence of individual control components of generators on the dynamics of their output parameters when operating as part of a stand-alone electric power system, which can cause poor electromechanical compatibility of equipment. The share of installed capacity of wind power plants relative to that of the diesel generator should not exceed $10 \%$ on average. This is due to the low electromechanical compatibility between diesel generators and wind turbines.

\section{Dynamic stability of generators}

The issues of stability of electric power systems were studied by a well-known Russian scientist Pyotr Sergeyevich Zhdanov. He conducted stability studies of two plants of comparable power. The equation that describes the power and torque angle relationships is as follows:

$$
T_{j} \frac{\partial^{2} \delta}{\partial t^{2}}=P_{0}-P_{m} \sin \delta
$$

where $T_{j}$ - rotor inertia constant, $P_{0}$ - turbine power, $P_{m}$ - electromagnetic power of the generator, $\delta$ - torque angle.

Solving this equation in form $\delta=f(t)$ provides an overview of the time-varying behavior of the angle and allows one to determine whether the machine remains in sync. This equation is non-linear. Therefore, special numerical methods are applied to solve it. One of them is the method of successive intervals, which is used to solve the problem in finite increments.

In the case of the problem that describes dynamics of two plants working in parallel, the finite increment will be of the following kind [9]:

$$
\Delta \delta=360 f\left(\frac{\Delta P_{1}}{T_{j 1}}-\frac{\Delta P_{2}}{T_{j 2}}\right) \frac{\Delta t^{2}}{2},
$$


where $f$ - grid frequency; $\Delta P_{1}$ - exchange power between the first generator and the system; $\Delta P_{2}-$ exchange power between the second generator and the system; $\Delta t$ - short-circuit time. It follows from the analysis of this equation that there are constraints on generator power and disturbance duration. Thus, the rationale behind the requirements put forward with respect to the mixes of power equipment to be added into the power system is provided.

\section{Ways to increase stability of the stand-alone power system}

Recently, the interest of researchers has been attracted to controlled magnetic and electromagnetic variators to establish flexible coupling between the turbine and the generator in order to stabilize operation mode parameters [15]. The use of magnetic and electromagnetic variators in the wind power engineering allows to increase reliability and life of generating equipment and to expand the scope of application of wind turbines, including that in the Arctic conditions. Application of electromagnetic variators in the designed wind-diesel hybrid power systems increases the utilization factor of the installed capacity of the wind farm and the share of renewable energy sources in the power system up to $40 \%[11,16]$.

Another way to increase the share of wind farms in stand-alone power systems with diesel generators is the use of energy storage devices, including electrochemical ones. In this case, the dynamic stability margin increases in proportion to the installed capacity of storage devices [17, 18].

To meet the conditions of normal operation of wind turbines operating in parallel with diesel generator, the following solutions can be highlighted.

1. Introduction of constraints on installed capacity of wind turbines depending on the total number and capacity of diesel generators.

2. Use of electrochemical energy storage facilities operating in a cyclic mode and acting as a stabilizing link [19].

3. Inclusion of an electromagnetic variator in the mix of wind turbines, which allows to smooth out disturbances in case of sharp changes in the operation mode [15].

Thus, the mix of energy equipment in the stand-alone power system can vary significantly depending on the chosen method of controlling the stability of wind turbines operating in parallel with diesel generators. In this study, the dynamic stability of a stand-alone power system of small capacity is ensured by introducing constraints on the equipment mixes that can be selected. Constraints are imposed on the share of the installed capacity of the wind farm depending on the capacity of the diesel generators, as well as on the capacity of storage batteres [13, 20].

\section{Method of reliability optimization}

In this study, three successively nested models are considered: a simulation model of power supply system operation, a model of reliability analysis, and a model of synthesis of power supply reliability of stand-alone hybrid power systems. Random values in the models are electrical load (electricity consumption, $\mathrm{kWh}$ ) and generation (electricity production, $\mathrm{kWh}$ ). The main sources of electricity are wind turbines and diesel generators, as well as storage batteries. Electricity generation depends on the values of random values of wind speed and air density in a given geographical area and failures of generating and grid equipment. Providing for capacity redundancy and installation of storage batteries are considered as means to ensure reliability of power supply. 
Variables in the reliability optimization problem are as follows: the number of wind turbines $r_{1}$, the number of diesel generators $r_{2}$, and storage battery capacity $r_{3}$. The set of the above values forms vector $r$ with components $r_{1}, r_{2}, r_{3}$. Optimized sets $r$ are determined with respect to the expected value of power consumption. Requirements to be met by power equipment in terms of electrodynamic stability entail the introduction of additional constraints on the set of vectors $r$. Let us denote the set of all the sets of equipment permissible with respect to electrodynamic stability as $R$.

\section{Model of operation of the power supply system}

The model serves as the basis for the power supply reliability analysis. The reliability analysis is based on multiple simulations of power supply system operation during four seasons of the year being modeled. Each season of the year is characterized by its own load profile, histograms of air density, and average hourly wind speed.

In what follows we provide a description of the model within one season of the year. Let us denote the sequential number of the hour in question as $k-, k=1, \ldots, K$. Here, $K-$ is the number of hours modeled for each season of the year. With the aid of the random number generator, for the $k$-th hour, the values of random variables are selected: $y^{k}$ - that of electricity consumption volume, $\mathrm{kWh} ; x^{k}-$ that of electricity production volume by wind turbines, $\mathrm{kWh}$. The power storage capacity $(\mathrm{kWh}) r_{3}$ is set, $s^{k}$ - is the remaining charge $(\mathrm{kWh})$ of the storage at the beginning of hour $k, k=1, \ldots, K$.

In those case when the demand for electricity exceeds its available amount, the electricity is undersupplied

$$
d^{k}=y^{k}-x^{k}-\min \left\{\alpha r 3, s^{k}\right\},
$$

where $\alpha$-is the charge-discharge factor of the storage battery, in the present study $\alpha=0,25$. Otherwise, $d^{k}=0$ i.e. $d^{k}=\max \left\{0, y^{k}-x^{k}-\min \left\{\alpha r_{3}, s^{k}\right\}\right\}$. The use of factor $\alpha$ in the model is due to the presence of charge-discharge power limits of the storage battery [19].

Shortage of electricity in the model under consideration is covered by its production by a diesel generator. When switched on, the diesel generator also charges the storage battery within acceptable limits. Let us denote by $\widetilde{x}^{k}$ - the volume of electricity produced by a diesel generator in the $k$-th hour, $\mathrm{kWh}, k=1, \ldots, K$. The value of $\widetilde{x}^{k}$ is determined as per the following equation

$$
\widetilde{x}^{k}=\max \left\{0, y^{k}-x^{k}\right\} .
$$

Diesel fuel is used to generate electricity by the diesel generator, the volume of its consumption is determined as per the following rule

$$
f^{k}=\tilde{x}^{k}
$$

where $v$ - is the coefficient of fuel consumption in kilograms for production of one kWh of electricity. The cost of diesel fuel spent on power generation is calculated on the basis of the value of $f^{k}$ and is included in operating costs. At the same time, the cost of fuel consumed is descriptive of the damage to consumers that could have been caused by electricity shortages. If the diesel generators fail, then a non-zero value $d^{k}$ will be referred to as the actual power shortage and will be denoted as $\widetilde{d}^{k}$. Otherwise

$\widetilde{x}^{k}=0$ and $\widetilde{d}^{k}=0$. The total actual undersupply of electricity for the season will amount to $D=\sum_{i=1}^{K} \widetilde{d}^{k}$. 
Changes in the residual charge value of storage batteries are determined according to the following rules:

- if $y^{k}>x^{k}$ and $\widetilde{d}^{k}>0$, then

$$
s^{k+1}=s^{k}-\min \left\{\alpha r_{3}, s^{k}\right\}
$$

- $\quad$ if $y^{k}>x^{k}$ and $\widetilde{d}^{k}=0$, then

$$
s^{k+1}=s^{k}
$$

- if $x^{k}>y^{k}$, then

$$
s^{k+1}=\min \left\{s^{k}+\min \left\{\alpha r_{3}, x^{k}-y^{k}\right\}, r_{3} .\right.
$$

The value of $s^{k+1}$ depends on the observed values of random variable $x^{k}-y^{k}$ (with probability density given and constant during the transition), the random variable of diesel generator failures, and the remaining charge level $s^{k}$. Hence, sequence $s^{1}, s^{2}, \ldots, s^{K}$ is a homogeneous Markov chain. Any value of random variable $\varepsilon$, evenly distributed within segment $\left[0, r_{3}\right]$, can be used as $s^{1}$.

As a result of running the model simulating the operation of the power supply system during the year, the amount of an increase in costs associated with the adoption of means to ensure reliability is determined. Let us denote this value as $C(r)$, mln rubles. Annual reliability assurance costs consist of its operating $C_{o p}(r)$ and capital $C_{c a p}(r)$ components

$$
C(r)=C_{o p}(r)+\gamma C_{c a p}(r)
$$

Here, $\gamma C_{c a p}(r)$ - is the amount of annual annuity payment, and $\gamma-$ is the annuity factor calculated as per the following equation

$$
\gamma=\frac{i(1+i)^{n}}{(1+i)^{n}-1}
$$

$i$ - the annual interest rate on the loan, expressed in hundredths, $n$ - the number of years during which the loan is paid off. In our study, we assume that $i=0,07, n=20$. In Russia, there is a common practice to use, instead of $C(r)$, net present costs where $\gamma$ acts as the reduction factor that is assumed to be equal to 0.12 for the electric power industry facilities. Application of one or another method of cost determination depends on the degree of power sector liberalization.

\section{Power supply reliability analysis}

Within the framework of the power supply reliability analysis model, four seasons of the power system operation in the year being modeled are considered and the following reliability indicators are calculated.

1. Estimation of the expected values of undersupply of electricity per year

$$
M D=\frac{\sum_{i=1}^{4} D_{i}}{4 K} 8760 .
$$

Here $D_{i}-$ is the total actual undersupply of electricity in the $\mathrm{i} t h, i=1, \ldots, 4$.

2. Estimation of probability of shortage situations 


$$
P=\frac{H}{4 K},
$$

where $H-$ is the total number of hours in all seasons, for which the value $\widetilde{d}$ is non-zero. Then the estimation of the probability of shortage-free operation of the electric power system is calculated as per rule $Q=1-P$.

3. Estimation of the expected value of the number of shortage hours per year

$$
M H=8760 P .
$$

In fact, this indicator is LOLH (Loss of load hour), a well-established reliability indicator, which is the average number of hours per year in which there is a load loss [21].

4. Estimation of the expected value of diesel generator fuel consumption per year and estimation of the expected value of annual fuel consumption cost

$$
M F=\frac{\sum_{i=1}^{4} \sum_{k=1}^{K} f_{i}^{k}}{4 K} 8760, M C_{f}=c_{f} M F .
$$

Here, $c_{f}-$ is the price of one kilogram of diesel fuel as denomated in rubles. In this study, we assumed the price of 60 rubles per $\mathrm{kg}$ of fuel with its delivery to the place of consumption factored in.

5. Evaluation of the expected value of the annual volume of generated electricity

$$
M X=\frac{\sum_{i=1}^{4} \sum_{k=1}^{K}\left(x_{i}^{k}+\tilde{x}_{i}^{k}\right)}{4 K} 8760,
$$

where $x_{i}^{k}$-is the volume of electricity produced by wind turbines in the $k$ th hour of the $i$ th season, $\mathrm{kWh}, \widetilde{x}_{i}^{k}$ - is the volume of electricity produced by a diesel generator in the $k$ th hour of the $i$ th season, $\mathrm{kWh} k=1, \ldots, K, i=1, \ldots, 4$.

6. Estimation of the expected value of electricity cost per $\mathrm{kWh}$

$$
M E=\frac{C(r)+M F}{M X} .
$$

It should be noted that the values of variables $M F$ and $M X$ depend on the mix of equipment selected and installed in the power system. Thus, the expected value of the cost of electricity is a function of $r$.

\section{Power supply reliability optimization model}

The model of power supply reliability optimization is presented as the following problem

$$
\begin{aligned}
& M E(r) \rightarrow \min . \\
& r \in R .
\end{aligned}
$$

This problem belongs to the class of nonlinear stochastic optimization problems in their discrete setting. The search for the optimal solution is carried out by the full enumeration method, by comparing the values of function $M E(r)$ as calculated with the aid of the Monte Carlo method. The reduction of computational time is achieved by significantly reducing the number of options under consideration. 


\section{Modeling power equipment}

When modeling the stand-alone power system, two modes of its operation are considered: parallel operation of wind turbines and a diesel generator; operation of wind turbines with storage batteries and a diesel generator used as a backup source of electricity. Characteristics of the power equipment are set: they are installed capacity of generating equipment, current and voltage values in cable and overhead lines, electrical losses, capacity, and state of charge of storage batteries.

\section{Modeling wind turbines}

In practice, two types of wind turbines are used: those with the horizontal and vertical axis of rotation, respectively. Horizontal axis wind turbines, usually three-bladed, became very common in constructing wind farms around the world. The unit capacity of the serial installation of this type varies from 0.1 to $5 \mathrm{MW}$.

Vertical axis wind turbines are well-proven in stand-alone and integrated low-power systems (up to $100-200 \mathrm{~kW}$ ). Such installations can be used in regions where the average wind speed at the height of the wind wheel installation is $4-5 \mathrm{~m} / \mathrm{s}$ due to the low breakaway speed.

The equation for calculation of generated power for two types of wind turbines is of the same form:

$$
P_{B \ni y}=\frac{s c_{p} \rho v^{3}}{2},
$$

where $s$ - is the swept area of the turbine surface, $\mathrm{m}^{2} ; c_{p}$ - power factor, p.u.; $\rho$ - air density, $\mathrm{kg} / \mathrm{m}^{3}$; $v$ - wind speed, $\mathrm{m} / \mathrm{s}$.

The swept area is calculated depending on the type of the wind turbine:

- horizonal axis rotation

$$
s=\pi r^{2},
$$

where $r$ - is radius of the windwheel, $\mathrm{m}$;

- vertical axis rotation

$$
s=h d,
$$

где $h$ - the height of a wind turbine blade, $d$ - diameter of the wind turbine, $\mathrm{m}$.

Air density with humidity factored in is determined as per the following equation

$$
\rho=\frac{\rho_{d} R_{v}+\rho_{v} R_{d}}{R_{d} R_{v} t}
$$

Here $\rho_{d}$ - dry air partial pressure, $\mathrm{Pa} ; R_{d}-$ dry air gas constant $(287,058 \mathrm{~J} / \mathrm{kg} \bullet \mathrm{K}) ; t$ - external air temperature, $\mathrm{K} ; \rho_{v}$ - water vapor pressure, $\mathrm{Pa} ; R_{v}-$ vapor constant $(461,495 \mathrm{~J} / \mathrm{kg} \bullet \mathrm{K})$.

Conversion of the wind speed to the height of the wind wheel installation

$$
v_{2}=v_{1}\left(h_{1} / h_{2}\right)^{\beta},
$$

where $v_{1}$-is the measured wind speed at a height of $10 \mathrm{~m}\left(h_{1}\right), v_{2}-$ is the adjusted wind speed at the working height $h_{2}, \beta$-is the roughness factor of the underlying surface.

This study uses horizontal and vertical axis wind turbines with installed capacity of $20 \mathrm{~kW}$ each. Table 1 shows the main technical characteristics of wind turbines and their cost. 
Table 1. Technical and economic characteristics of wind turbines

\begin{tabular}{|c|c|c|}
\hline & Vertical axis wind turbine & Horizontal axis wind turbine \\
\hline Installed capacity, $\mathrm{kW}$ & 20 & 20 \\
\hline Power factor, $\mathrm{p} . \mathrm{u}$. & 0.39 & 0.45 \\
\hline Swept area, $\mathrm{m}$ & 30 & 36 \\
\hline Initial speed, $\mathrm{m} / \mathrm{s}$ & 1.5 & 2.5 \\
\hline Equipment cost, $\mathrm{mln}$. rubles & 1.25 & 1.32 \\
\hline
\end{tabular}

\section{Making up arrangement options of the energy storage system}

In this study, the method of classifying storage batteries depending on the operating conditions is used. The main purpose of this method is to form such options of the storage battery arrangement where the modes of operation will meet normal operating conditions. When making up mixes of equipment the following parameters are estimated: discharge current ratio, actual values of charge and discharge current, time intervals at which the state of charge of storage batteries is low charge. The values of these parameters are calculated according to the algorithms described in [19].

The integration of the approach described in the article [19] allows to define such storage battery technologies that meet all necessary requirements of engineering and regulatory documentation.

As a result of solving the problem of storage batteries classification, there were obtained alternative arrangements with OPzS and FLA type storage batteries using the electrolyte circulation system.

\section{Characteristics of storage batteries}

In this study, flooded lead-acid storage batteries of the OPzS type with the capacity of $1000 \mathrm{~A}-\mathrm{h}$ and rated voltage of $2 \mathrm{~V}$ are used as electric power storage. A special feature of these storage batteries is the use of tubular positive plate, which significantly increases the number of charge-discharge cycles. This type of storage batteries has 1,500 to 2,000 charge-discharge cycles at $80 \%$ depth of discharge. In addition, OPzS type storage batteries have high rated charge-discharge currents, which are $25 \%$ of the installed capacity.

The storage battery wiring scheme is formed based on the limitations of the battery inverter. Standard wiring schemes are often made for the voltage of $48 \mathrm{~V}$, or, in some cases, $96 \mathrm{~V}$. This paper considers the $48 \mathrm{~V}$ wiring scheme, which corresponds to 24 storage batteries connected in series, with a total capacity of $48 \mathrm{kWh}$. Then, other assemblies of similar capacity and wiring schemes are connected to this group of storage batteries. Thus, storage batteries were added to the optimized mix of the equipment in series of 24 units. The cost of OPzS storage batteries manufactured in Russia is 35 thousand rubles per unit with the capacity of $2 \mathrm{kWh}$.

\section{Object of the study}

As the object of the study we considered a stand-alone hybrid power system that was assumed to be located in the coastal area of Lake Baikal in Kabansky State Nature Reserve (Kabansky District, Republic of Buryatia, Russia). 


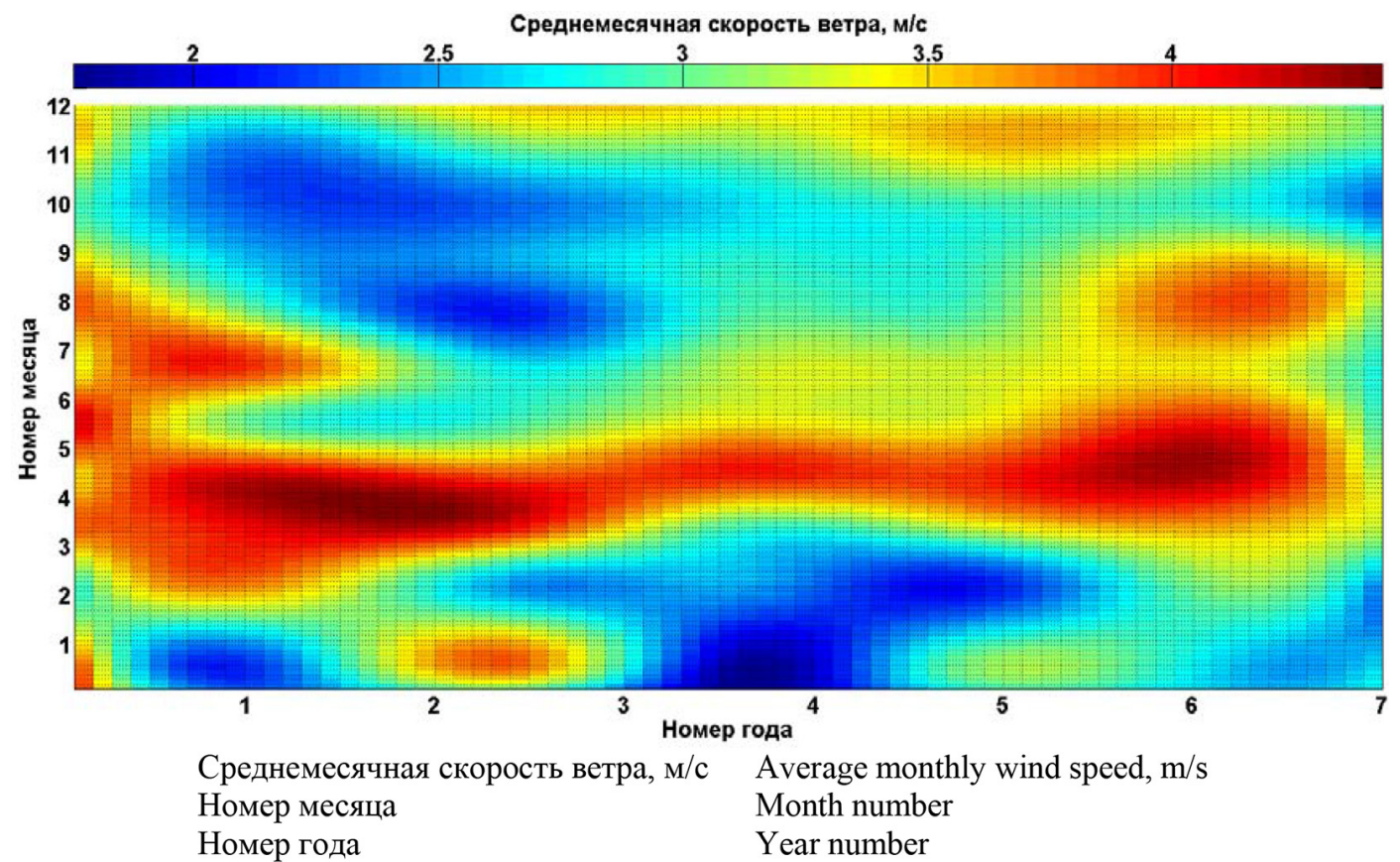

Fig. 1. Wind speed in Kabansky District of the Republic of Buryatia, Russia, according to long-term weather data series

Simulation of hourly wind speed is based on FM 12 Synop weather data. These data are presented in the form of multi-year weather data series. Automatic processing, data generation, elimination of erroneous measurements are performed with the help of the software and computing system "Local analysis of environmental parameters and solar radiation" [19].

The analysis of weather data for a ten-year period (Fig. 1) shows that wind speed in the winter-summer period averages $3.5-4.5 \mathrm{~m} / \mathrm{s}$ at the height of 10 meters. Low temperatures in the fall-winter period ensure high air density, which on average increases electricity production by $15-25 \%$.

This study uses data of hourly changes in the electrical load on the part of the consumer. The nature of the load characteristic is that of a classic shape with two peaks in the morning and evening hours, as adjusted for the season. Random fluctuations of the electrical load are simulated by means of a random number generator within a given range of values. Maximum load is observed in winter and equals $26 \mathrm{kWh}$. Annual electricity consumption is about 180 thousand $\mathrm{kWh}$.

A stand-alone hybrid power system is made up of low capacity wind turbines, $0.4 \mathrm{kV}$ power lines, diesel-powered generator set (DPGS), incoming switchgear (ISG), battery inverters, and storage batteries (Fig. 2).

The operation of the generation system is performed as per the following algorithm.

- If generation by wind turbines is enough for direct supply of the consumer and there is surplus energy, it is accumulated in storage batteries.

- If there is a shortage of power, it is covered by storage batteries, taking into account the technical limitations with respect to the discharge rate. 


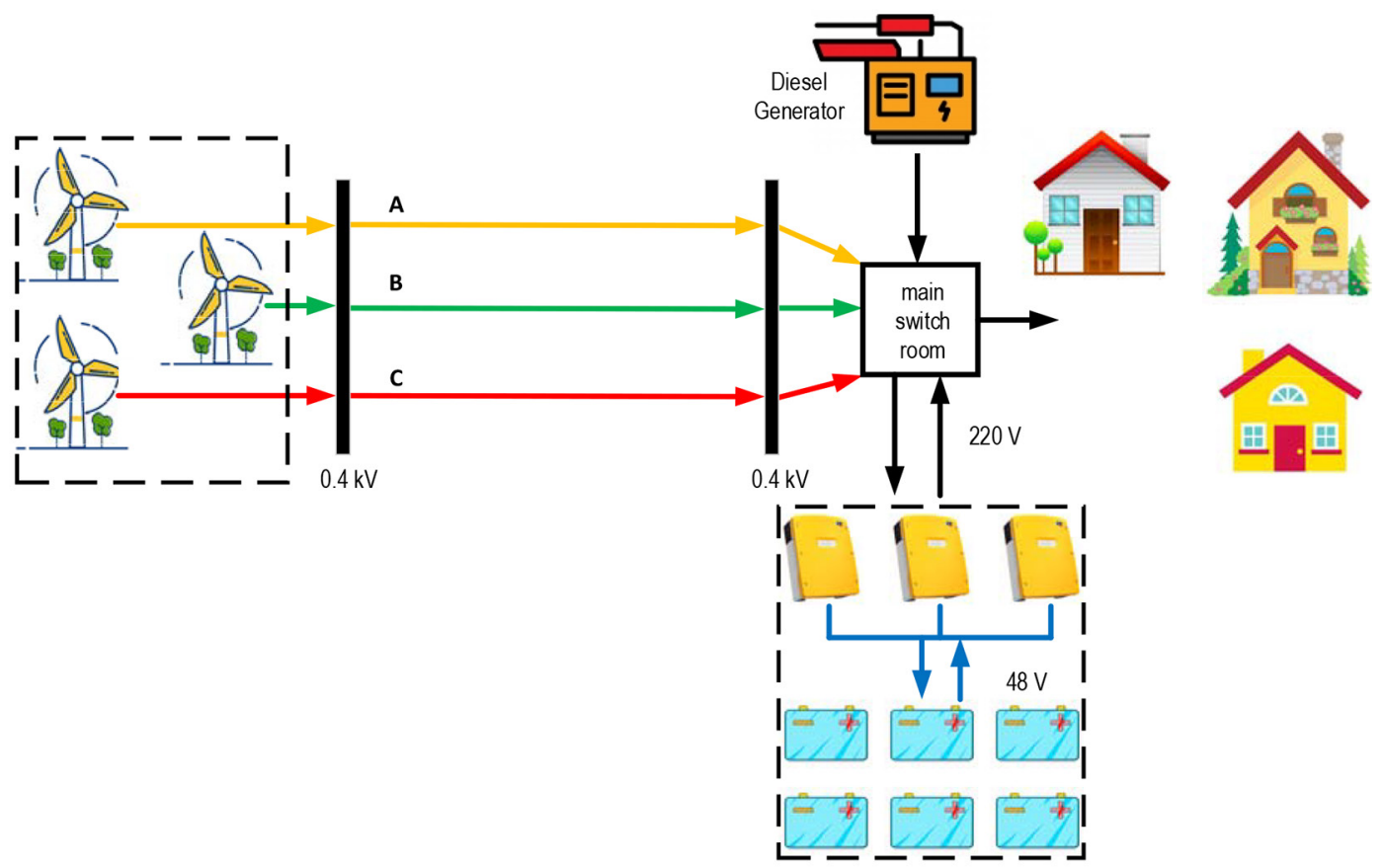

Fig. 2. Diagram of the stand-alone hybrid power system

- If there is insufficient power and the storage batteries have a low state of charge, a backup source is activated. The backup source starts at full power, thus supplying the consumer and recharging the storage batteries.

A diesel generator with a capacity of $80 \mathrm{~kW}$ and cost of 1 million rubles is used as a backup power source.

\section{Reliability optimization results}

Based on the requirements to be met by electrical equipment with respect to dynamic stability and constraints imposed on discharge-charge modes of storage batteries, mixes of equipment for horizonatal axis wind turbines and vertical axis wind turbines were formed. For the selected mixes of the equipment the resource adequacy analysis was carried out within the specified load profiles. The results of the reliability analysis were summarized in the form of tables. Equipment combinations, which are characterized by the lowest cost of generated electricity, were considered optimal.

The results of reliability optimization of the stand-alone electric power system are presented twofold: as reliability indicators (Table 2 and Table 3); as cost indicators (Table 4 and Table 5).

The presented tables demonstrate that for all mixes of the equipment the required value of the probability of shortage-free operation of 0,996 is achieved.

An optimal (with respect to the criterion of minimum cost of generated electricity) installation is that of two horizontal axis wind turbines and a storage battery with a capacity of $96 \mathrm{kWh}$, or a single vertical axis wind turbine and a storage battery with a capacity of $96 \mathrm{kWh}$ in the stand-alone power system. The lowest cost per $\mathrm{kWh}$ is achieved in the second case amounting to 10 rubles 43 kopecks. It should be noted that from the point of view of diesel fuel costs the second option is less preferable as it 
Table 2. Reliability indicators for the stand-alone power system with horizontal axis wind turbines

\begin{tabular}{|c|c|c|c|c|}
\hline $\begin{array}{c}\text { Number of wind } \\
\text { turbines, pcs }\end{array}$ & $\begin{array}{c}\text { Storage battery } \\
\text { capacity, kWh }\end{array}$ & $\begin{array}{c}\text { Estimate of } \\
\text { probability of } \\
\text { shortage-free } \\
\text { operation }\end{array}$ & $\begin{array}{c}\text { Estimate of the } \\
\text { expected value of the } \\
\text { number of shortage } \\
\text { hours per year }\end{array}$ & $\begin{array}{c}\text { Estimate of the } \\
\text { expected value of } \\
\text { electricity undersupply, } \\
\text { kWh per year }\end{array}$ \\
\hline 1 & 0 & 0.9982 & 16.2 & 297.1727 \\
\hline 1 & 48 & 0.9983 & 15 & 193.0797 \\
\hline 1 & 96 & 0.9991 & 7.6 & 100.1807 \\
\hline 2 & 96 & 0.9986 & 12.2 & 78.2069 \\
\hline 2 & 48 & 0.9991 & 11.8 & 142.9593 \\
\hline 3 & 96 & 0.9987 & 7 & 80.5415 \\
\hline 3 & & 0.9992 & & \\
\hline
\end{tabular}

Table 3. Reliability indicators for the stand-alone power system with vertical axis wind turbines

\begin{tabular}{|c|c|c|c|c|}
\hline $\begin{array}{c}\text { Number of wind } \\
\text { turbines, pcs }\end{array}$ & $\begin{array}{c}\text { Storage battery } \\
\text { capacity, kWh }\end{array}$ & $\begin{array}{c}\text { Estimate of } \\
\text { probability of } \\
\text { shortage-free } \\
\text { operation }\end{array}$ & $\begin{array}{c}\text { Estimate of the } \\
\text { expected value of the } \\
\text { number of shortage } \\
\text { hours per year }\end{array}$ & $\begin{array}{c}\text { Estimate of the } \\
\text { expected value of } \\
\text { electricity undersupply, } \\
\text { kWh per year }\end{array}$ \\
\hline 1 & 0 & 0.9984 & 13.9 & 265.7143 \\
\hline 1 & 48 & 0.9984 & 14.3 & 203.8393 \\
\hline 1 & 96 & 0.9990 & 8.5 & 98.3118 \\
\hline 2 & 48 & 0.9985 & 12.8 & 158.6386 \\
\hline 2 & 96 & 0.9989 & 9.3 & 168.1155 \\
\hline 3 & 98 & 0.9984 & 13.7 & 65.8131 \\
\hline 3 & 96 & 0.9991 & 8.1 & \\
\hline
\end{tabular}

Table 4. Cost indicators for the stand-alone power system with horizontal axis wind turbines

\begin{tabular}{|c|c|c|c|c|}
\hline $\begin{array}{c}\text { Number of wind } \\
\text { turbines, pes }\end{array}$ & $\begin{array}{c}\text { Storage battery } \\
\text { capacity, } \mathrm{kWh}\end{array}$ & $\begin{array}{c}\text { Costs of ensuring } \\
\text { reliability, mln. } \\
\text { rubles per year }\end{array}$ & $\begin{array}{c}\text { Estimate of the } \\
\text { expected value of the } \\
\text { cost of fuel consumed, } \\
\text { mln. rubles per year }\end{array}$ & $\begin{array}{c}\text { Estimate of the } \\
\text { expected value of the } \\
\text { cost per kWh, rubles }\end{array}$ \\
\hline 1 & 0 & 0.3299 & 1.7829 & 12.1365 \\
\hline 1 & 48 & 0.4635 & 1.4139 & 10.7830 \\
\hline 1 & 48 & 0.5971 & 1.2626 & 10.6929 \\
\hline 2 & 96 & 0.6190 & 1.2539 & 10.7657 \\
\hline 2 & 48 & 0.7525 & 1.1047 & 11.1007 \\
\hline 3 & 96 & 0.7745 & 1.1577 & 10.9652 \\
\hline 3 & & 0.9080 & 0.9993 & \\
\hline
\end{tabular}

requires $1773 \mathrm{~kg}$ more fuel consumption. Additional advantages of installing two horizontal axis wind turbines and a $96 \mathrm{kWh}$ battery are a lower estimate of the expected value of power undersupply (78.21 kWh per year) and a smaller number of shortage hours per year. 
Table 5. Cost indicators for the stand-alone power system with vertical axis wind turbines

\begin{tabular}{|c|c|c|c|c|}
\hline $\begin{array}{c}\text { Number of wind } \\
\text { turbines, pcs }\end{array}$ & $\begin{array}{c}\text { Storage battery } \\
\text { capacity, kWh }\end{array}$ & $\begin{array}{c}\text { Costs of ensuring } \\
\text { reliability, mln. } \\
\text { rubles per year }\end{array}$ & $\begin{array}{c}\text { Estimate of the } \\
\text { expected value of the } \\
\text { cost of fuel consumed, } \\
\text { mln. rubles per year }\end{array}$ & $\begin{array}{c}\text { Estimate of the } \\
\text { expected value of the } \\
\text { cost per kWh, rubles }\end{array}$ \\
\hline 1 & 0 & 0.339 & 1.7470 & 11.9847 \\
\hline 1 & 48 & 0.472 & 1.3799 & 10.6420 \\
\hline 1 & 96 & 0.606 & 1.2111 & 10.4378 \\
\hline 2 & 48 & 0.636 & 1.2527 & 10.8589 \\
\hline 2 & 96 & 0.770 & 1.0565 & 10.5008 \\
\hline 3 & 48 & 0.801 & 1.1490 & 11.2039 \\
\hline 3 & 96 & 0.934 & 0.9489 & 10.8084 \\
\hline
\end{tabular}

\section{Conclusion}

Methodology for selection of optimal equipment mix in the stand-alone power system with the wind turbine and electric power storage to ensure reliable power supply was developed. The criterion of reliability optimization is the minimum expected value of the cost of produced electricity. The estimation of the expected value of the cost of electricity is determined by the Monte Carlo method. The key feature of the approach developed is a detailed treatment of electrical equipment characteristics and requirements for electrodynamic stability. This is what contributes to a reduction in the total number of considered equipment mixes that guarantee the stability of stand-alone power system operation and, as a consequence, in the volume and time of computations.

When modeling the power equipment, the method takes into account its operation specifics that define operational constraints. As a case in point, taking into account the physical and chemical processes occurring in the process of charging-discharging of the storage battery implies setting the requirement for a maximum charge-discharge of $25 \%$ of the storage battery capacity. To extend the storage battery life, complete discharge is not recommended, which imposes an additional constraint on the utilized storage battery capacity and, as a result, on the equipment mix being optimized. Modeling of wind turbines involves taking into account not only the constraints imposed on dynamic stability, but also those imposed on the breakaway speed, and conditions for stopping wind turbines.

The use of detailed weather data in the reliability optimization methodology allows increasing the reliability of modeled climatic parameters affecting the power generation by wind turbines. Thus, the validity of the results of calculations performed within the framework of the methodology and the conclusions obtained gets enhanced.

A practical evaluation of the method was carried out based on the example of a stand-alone hybrid power system that was assumed to be located in the coastal area of Lake Baikal in Kabansky State Nature Reserve, Kabansky District, Republic of Buryatia, Russia. For the stand-alone power system being designed we considered horizontal and vertical axis wind turbines. Flooded lead-acid batteries of the OPzS type were used as energy storage devices. The diesel generator served as a backup power source. The results of the experiment demonstrated that within the framework of the considered natural climatic zone and load characteristics of the consumer, vertical axis wind turbines proved more efficient than horizontal axis wind turbines. This research finding can be used as a recommendation 
for installing vertical axis wind turbines in small stand-alone power systems in regions with limited wind power potential.

\section{References}

[1] Крупенев Д. С., Пержабинский С. М. Алгоритм оптимизации балансовой надежности электроэнергетических систем. Известия Российской академии наук. Энергетика, 2014, 2, 96106 [Krupenev D.S., Perzhabinsky S.M. Adequacy optimization algorithm of electric power systems, Izv. RAN. Energetika., 2014, 2, 96-106. (in Russian)]

[2] Heylen E., Deconinck G., Hertem D. Review and classification of reliability indicators for power systems with a high share of renewable energy sources, Renewable and Sustainable Energy Reviews, 2018, 97, 554-568

[3] Assaf J., Shabani B. A novel hybrid renewable solar energy solution for continuous heat and power supply to standalone-alone applications with ultimate reliability and cost effectiveness, Renewable Energy, 2019, 138, 509-520

[4] Johnson S.C., Papageorgiou D.J., Mallapragada D.S., Deetjen T.A., Rhodes J.D., Webber M.E. Evaluating rotational inertia as a component of grid reliability with high penetrations of variable renewable energy, Energy., 2019., 180, 258-271.

[5] Scheu M.N., Kolios A., Fischer T., Brennan F. Influence of statistical uncertainty of component reliability estimations on offshore wind farm availability, Reliability Engineering \& System Safety, 2017, 168, 28-39

[6] Григорьева О. А., Кривенко Т. В., Тремясов В. А. Анализ надежности автономного ветродизельного комплекса, Научно-технические ведомости СПбПУ. Eстественные и инженерные науки, 2016, 2 (243), 45-52 [Grigorieva O.A., Krivenko T.V., Tremyasov V.A. Reliability analysis of the stand-alone wind-diesel combined system, Nauchno-tekhnicheskie vedomosti Sankt-Peterburgskogo gosudarstvennogo politekhnicheskogo universiteta, 2016, 2 (243), 45-52. (in Russian)]

[7] Kovalev G. F., Lebedeva L. M. Reliability of power systems, Springer International Publishing, 2019. Vol. 1. 157 p.

[8] Андреюк В. А., Асанбаев Ю. А., Сказываева Н. С. Динамическая устойчивость энергосистемы при регулировании мощности турбин генераторов по абсолютному углу, Электрические станции, 2005, 12, 11-16. [Andreyuk V.A., Asanbaev Yu.A., Skazyvaeva N.S. Dynamic stability of the power system when controlling the generator turbine power by the absolute angle, Elektricheskie stancii, 2005, 12, 11-16. (in Russian)]

[9] Жданов П. С. Вопросы устойчивости электроэнергетических систем, М.: Энергия, 1979, 456c. [Zhdanov P.S. Sustainability issues in energy systems, Moscow, Energiya, 1979, 456 p. (in Russian)]

[10] Gazizova O.V., Allayarov A.A., Kondrashova Yu.N., Patshin N.T. Determining limits of dynamic stability of industrial power plant generators taking into account the motor load // Elektrotekhnicheskie sistemy i kompleksy. - 2018. - No. 2 (39). - P. 34-40. (In Russian)

[11] Son D.H., Muhammad A., Kang S.H., Heo J.H., Nam S.R. A method for increasing the operating limit capacity of wind farms using battery energy storage systems with rate of change of frequency. Energies, 2018, 4(11), 1-22 
[12] Amutha N., Kumar B.K. Improving fault ride-through capability of wind generation system using DVR. International Journal of Electrical Power \& Energy Systems, 2013, 46, 326-333

[13] Tripathy S.C., Kalantar M., Balasubramanian R. Dynamics and stability of a hybrid winddiesel power system. Energy Conversion and Management, 12(33), 1063-1072.

[14] Удалов С. Н., Приступ А. Г., Ачитаев А. А. Исследование магнитной трансмиссии с переменным передаточным отношением в ветроэнергетической установке в целях повышения запаса динамической устойчивости. Известия Томского политехнического университета. Инжиниринг георесурсов, 2015, 10(326) [Udalov S.N., Pristup A.G., Achitaev A. A. A study of the magnetic transmission with a variable transmission ratio in the wind turbine for the purposes of increasing the dynamic stability redundancy. Izvestiya Tomskogo politekhnicheskogo universiteta. Inzhiniring georesursov, 2015, 10(326), 123-134. (in Russian)]

[15] Udalov S.N., Achitaev A.A., Pristup A.G., Bochenkov B.M., Pankratz Y., Tarbill R.D. Increasing the regulating ability of a wind turbine in a local power system using magnetic continuous variable transmission. Wind Engineering, 2018, 42, 411-435

[16] Tang L., Zavadil R.M. Simulation of operational and control characteristics of hybrid winddiesel energy systems using the electromagnetic transients program. ASME, 1993, 14, 59-66

[17] Delille G., Francois B., Malarange G. Dynamic frequency control support by energy storage to reduce the impact of wind and solar generation on isolated power system's inertia. IEEE Transactions on sustainable energy. 2012, 4(3), 931-939

[18] Merino J., Sanchez J.A., Veganzones C., Martinez S. Power system stability of a small sized isolated network supplied by a combined wind-pumped storage generation system: a case study in the Canary Islands. Energies. 2012, V. 7(5), 2351-2369

[19] Карамов Д. Н. Интеграция процесса категоризации электрохимических накопителей энергии в задачу оптимизации состава оборудования автономных энергетических комплексов, использующих возобновляемые источники энергии. Известия Томского политехнического университета. Инжиниринг георесурсов. 2019, 5(330), 113-130 [Karamov D.N. Integration of the process of electrochemical energy storage classification into the problem of optimization of the equipment mix of stand-alone hybrid power systems that employ renewable energy sources. Izvestiya Tomskogo politekhnicheskogo universiteta. Inzhiniring georesursov. 2019, 5(330), 113-130 (in Russian)]

[20] S. Furta The dynamic stability of an elastic column. Journal of Applied Mathematics and Mechanics, 1990, 54, 769-776

[21] Чукреев Ю. Я. Показатели балансовой надежности и их нормирование при управлении развитием электроэнергетических систем: информационный аспект. Известия Российской академии наук. Энергетика, 2015, 5, 33-44. [Chukreev Yu.Ya. The assessment features of the adequacy indicators and their rationing at the management of power dystem development. Izvestiya RAN. Energetika. 2015, 5, 33-44 (in Russian)] 